\title{
Wpływ orzeczeń sądów administracyjnych na ochronę ładu przestrzennego w lokalnym planowaniu przestrzennym
}

\section{Streszczenie}

Celem artykułu jest określenie wpływu wywieranego przez orzecznictwo sądów administracyjnych na praktykę planistyczną w zakresie ochrony ładu przestrzennego. Zweryfikowano ten wpływ z perspektywy dwóch kluczowych stosowanych w praktyce (przez sądy, organy jednostek samorządu terytorialnego, uczestników gry o przestrzeń) systemów informacji prawnej: LEX i Legalis. To właśnie tezy orzecznicze zawarte w wymienionych systemach stanowią podstawę dla wyrażanych w kolejnych sprawach ocen oraz formułowania argumentów. Wybrano dwa kluczowe z perspektywy ochrony ładu przestrzennego i zakresu prawa własności w systemie gospodarki przestrzennej przepisy: art. 2 pkt 1 oraz art. 6. Wyniki wskazują, że w badanych systemach dominują orzeczenia ze wskazanej perspektywy neutralne. Niemniej bardzo silna jest reprezentacja orzeczeń umożliwiających poszerzanie możliwości zabudowy. Kluczowa wydaje się w tym kontekście reprezentacja orzeczeń w sposób bardziej precyzyjny definiujących ład przestrzenny, jak również wprost wskazujących nadrzędność ładu przestrzennego nad prawem własności. Pomimo braku klarownych podstaw prawnych sądy administracyjne powinny właśnie na ten kierunek zwrócić szczególną uwagę.

Słowa kluczowe: polityka przestrzenna, ład przestrzenny, prawo własności, orzecznictwo Kody klasyfikacji JEL: R50, K49

1 Zachodniopomorski Uniwersytet Technologiczny, Wydział Ekonomiczny, e-mail: macnowak@zut. edu.pl, https://orcid.org/0000-0001-8149-8995 


\title{
Impact of administrative court decisions on the protection of spatial order in local spatial planning
}

\begin{abstract}
The article aims to determine the influence of administrative courts' jurisprudence on planning practice in the field of spatial order protection. This impact was verified from the perspective of two key, practical (used by courts, local government units, participants in the space game), and legal information systems: LEX and Legalis. The jurisprudence theses contained in the systems mentioned above constitute the basis for the judgments and formulation of arguments expressed in subsequent cases. Two key provisions were selected, important from the perspective of the protection of spatial order and the scope of property rights in the spatial management system: Art. 2, point 1, and Art. 6 . The results show that in the examined systems, neutral judgments dominate. Nevertheless, the representation of decisions enabling the expansion of development possibilities is forceful. In this context, the key decisions seem to be more precise, defining the spatial order and directly indicating the superiority of the spatial order over the ownership right. Despite the lack of a clear legal basis, administrative courts should pay particular attention to this direction.
\end{abstract}

Keywords: spatial policy, spatial order, property right, jurisprudence

JEL Classification Codes: R50, K49

Rola sądów w systemie gospodarki przestrzennej stanowi przedmiot licznych dyskusji (związanych ze zróżnicowanymi punktami widzenia). W kontekście nauk o polityce publicznej bardzo istotne wydaje się określenie, w jakim zakresie orzecznictwo sądowe powinno stanowić rozwiązanie występujących w systemie gospodarki przestrzennej problemów czy odpowiedź na nie. Wymaga to z jednej strony szczegółowej weryfikacji stanu obecnego, a z drugiej - krytycznej (również z perspektywy prawnej) oceny. Z jednej strony nie można bowiem roli sądów przeceniać i np. oczekiwać nietypowych wykładni prawa, ale z drugiej bardzo często obecna formuła procedur sądowo-administracyjnych nie gwarantuje ochrony kluczowych wartości przestrzennych. Wręcz przeciwnie, może pośrednio doprowadzić do ich dalszej degradacji.

Celem artykułu jest określenie wpływu wywieranego przez orzecznictwo sądów administracyjnych na praktykę planistyczną w zakresie ochrony ładu przestrzennego. Opierając się na (powołanych) tezach literatury przedmiotu, autor wywodzi ten wpływ z podejścia sądów do zagadnień związanych z rozumieniem ochrony prawa własności i ochrony ładu przestrzennego. Niniejsze zagadnienie jest postrzegane bardziej 
systemowo niż indywidualnie. Nie chodzi o ujęcie, zgodnie z którym konkretny wyrok skutkuje pogłębianiem chaosu przestrzennego w konkretnej indywidualnej sprawie. Sytuacja taka może, ale nie musi występować. Chodzi raczej o rezultaty, które taki wyrok przynosi dla szerszej praktyki (orzeczniczej, samorządowej). Dana teza orzecznicza wywołuje bowiem skutki również w kontekście dalszej wykładni przepisów. Nawiązując do wcześniejszych badań z tego zakresu, zweryfikowano wpływ z perspektywy dwóch kluczowych stosowanych w praktyce (przez sądy, organy jednostek samorządu terytorialnego, uczestników gry o przestrzeń) systemów informacji prawnej: LEX i Legalis. To właśnie tezy orzecznicze zawarte w wymienionych systemach stanowią podstawę dla wyrażanych w kolejnych sprawach ocen oraz formułowania argumentów. Wybrano dwa kluczowe pod tym względem przepisy ustawy z dnia 27 marca 2003 r. o planowaniu i zagospodarowaniu przestrzennym: art. 2 pkt 1 oraz art. 6. Pierwszy z nich, art. 2 pkt 1, zawiera (ogólną) definicję ładu przestrzennego i dopasowane do niego w systemach informacji prawnej tezy orzecznicze określające ramy możliwego zastosowania tej definicji w praktyce. Z kolei art. 6 dotyczy sposobu wykonywania prawa własności przy stosowaniu narzędzi polityki przestrzennej i w konsekwencji ograniczeń z tym związanych.

Orzeczenia dopasowane do obu tych przepisów sklasyfikowano z perspektywy wpływu na ład przestrzenny (co czasem sprowadza się do poszerzenia lub ograniczenia w indywidualnym przypadku możliwości zabudowy). Zróżnicowanie tych kierunków nie oznacza od razu całkowitej sprzeczności tez wyodrębnionych grup - dotyczą one zróżnicowanych stanów faktycznych. Niemniej przedmiotowa klasyfikacja ważna jest $\mathrm{z}$ jednego powodu - obrazuje ona wpływ orzeczeń na system gospodarki przestrzennej i kluczowe w tym zakresie tendencje.

\section{Orzecznictwo w systemie gospodarki przestrzennej - przegląd literatury przedmiotu}

Przy określaniu relacji między prawem a praktyką planistyczną trzeba się odwołać do tez formułowanych w zagranicznej literaturze przedmiotu, znajdujących zastosowanie we wszystkich systemach gospodarki przestrzennej. Zgodnie z nimi prawo nie definiuje danego systemu. Jest to jedynie swoisty „korytarz”, w którym mieści się praktyka planistyczna (Reimer, Getimis, Blotevogel, 2014: 1-20). W licznych analizach systemu gospodarki przestrzennej w Polsce wielokrotnie zwracano uwagę na rolę prawa. W przeważającym zakresie są to uwagi krytyczne. Po pierwsze, obecne rozwiązania prawne wciąż sankcjonują pogłębiający się chaos przestrzenny (i jego koszty). Fakultatywność i niedookreślona z perspektywy cech morfometrycznych formuła 
planów miejscowych, brak realnych ograniczeń masowych odrolnień, a także niejednoznacznie sformułowane przesłanki wydawania decyzji o warunkach zabudowy od wielu lat stanowią przedmiot uzasadnionej krytyki (Cotella, 2014: 255-277; Kowalewski et al., 2014: 5-21; Kowalewski, 2019: 267-267; Kudłacz, 2015: 31-42; Markowski, 2010: 12-31; Nowak, 2012: 55-82; Nowak, Kreja, 2012: 4-9; Nowak, 2017a: 101-142). Z drugiej jednak strony rozważenia wymaga również doprecyzowanie roli prawa w systemie gospodarki przestrzennej. Prawo nie da rady nigdy samodzielnie dookreślić wszystkich zagadnień (Izdebski, 2013: 150; Korbel, 2017: 103-116; Markowski, 2011: 25-44; Parysek, 2010: 33-44; Zybała, 2019:103-122). Konieczne jest tu również wyrażenie dbałości o sprawność władz publicznych czy też poziom kapitału społecznego.

Nie zmienia to jednak faktu, że prawo jest istotne również przy okazji rozwiązywania konfliktów przestrzennych, choć także przy tej okazji nie można się do stosowania prawa ograniczać (Nowak, 2017b: 22-35). Konflikty te często są ostatecznie rozwiązywane przez sądy administracyjne (wojewódzkie sądy administracyjne, a po wniesieniu skargi kasacyjnej również Naczelny Sąd Administracyjny). Najczęściej sprowadza się to do:

- rozpatrywania przez sądy administracyjne skarg na miejscowe plany zagospodarowania przestrzennego,

- rozpatrywania przez sądy administracyjne skarg w przedmiocie decyzji o warunkach zabudowy (w sytuacji, gdy organ odwoławczy, czyli samorządowe kolegium odwoławcze, nie podzieli racji skarżącego).

Zarzuty mogą dotyczyć zarówno spraw proceduralnych, jak też materialnych (Rzucidło, 2020: 20-75). W przedmiotowym przypadku kluczowe są te ostatnie. Trzeba jednak podkreślić, że z perspektywy niniejszego artykułu przedmiotem analizy są tezy orzecznicze z tej drugiej grupy. Tym bardziej, że analitycy rozwiązań prawnych (ale także roli sądów w systemie gospodarki przestrzennej) dokonując krytyki, mają na uwadze właśnie te tezy. To powiązane z nimi wyroki mają ugruntowywać chaos przestrzenny w Polsce (Kowalewski, Nowak, 2018: 128-136). W tym miejscu trzeba zastrzec, że z perspektywy prawnej kluczowe jest właściwe ujęcie roli sądów. Dokonują one wykładni obowiązujących przepisów: muszą więc opierać się na obowiązujących przepisach (z ich wszystkimi wadami). Nie mogą natomiast dokonywać oddolnej korekty systemu gospodarki przestrzennej wbrew tym regulacjom. Czasami jednak nawet tego typu próby w orzecznictwie można zauważyć. Najlepszym przykładem jest przesądzanie o kwestii wymogu zgodności decyzji o warunkach zabudowy ze studium uwarunkowań i kierunków zagospodarowania przestrzennego. Brzmienie ustawy o planowaniu i zagospodarowaniu przestrzennym nie daje podstaw do konkluzji, zgodnie z którą taki związek w obecnie obowiązujących przepisach został 
ujęty. Natomiast z perspektywy potrzeb systemu gospodarki przestrzennej byłby on zdecydowanie wskazany. Powyższe nie upoważnia jednak sądów do stwierdzania (na podstawie obecnie obowiązujących przepisów) takiego wymogu. Jest to zbyt daleko idące (i tak ocenić należy indywidualne wyroki preferujące taki kierunek orzeczniczy). Powyższy przykład obrazuje, że w pewnych przypadkach oczekiwania względem sądów są zbyt daleko idące. $Z$ drugiej strony nie usprawiedliwia to wszystkich tez orzeczniczych. Można bowiem - właśnie w tych ramach swobody przy dokonywaniu wykładni, zauważyć zarówno tezy silniej akcentujące kwestie ochrony ładu przestrzennego i interesu publicznego, jak też tezy podkreślające prawa właścicieli nieruchomości. Kierunki wykładni szerzej uwzględniającej ochronę ładu przestrzennego, a także jej uwarunkowania i możliwe zmiany, są również zawarte w literaturze przedmiotu (Gdesz, 2020: 46-65; Krawczyk, 2018: 33-44; Nowak, Lorens 2020: 104-128; Nowak, 2020: 15-23, Ostrowska, 2017: 153-170, Zachariasz, 2015: 118-134; Woźniak, 2018:21-33). W przeprowadzonych badaniach dotyczących województwa mazowieckiego (i orzeczeń wydawanych przez WSA w Warszawie) zauważalne jest zróżnicowanie ilościowe tego typu orzeczeń. Rzecz jasna wiele zależy od konkretnych stanów faktycznych (Nowak, Śleszyński, Ostrowska, 2020: 109-128). Niemniej schemat dokonywanej oceny bywa zbliżony i zasugerowany kierunek kategoryzacji tez należy uznać za ważny i potrzebny. Jest to istotne nie tylko z perspektywy konkretnych skutków w ramach określonego stanu faktycznego, ale też dalszego odbioru danej tezy orzeczniczej przez praktykę (jako swoistego wzorca, punktu odniesienia dla podobnej wykładni przepisów w przyszłości). Nie budzi wątpliwości, że w obecnym systemie gospodarki przestrzennej wpływ regulacji prawnych na praktykę planistyczną jest bardzo duży (Izdebski et al., 2018: 331-340; Majda, 2020: 129-158; Markowski 2014: 335-367; Śleszyński, 2018a: 404-424, Śleszyński, 2018b: 29-80, Śleszyński et al., 2020: 2-28).

\section{Wyniki}

W związku z realizacją celu pracy wybrano wszystkie tezy orzecznicze przyporządkowane w systemach informacji prawnej Legalis i LEX (najbardziej popularnych i uznanych) do art. 2 pkt 1 oraz art. 6 ustawy o planowaniu i zagospodarowaniu przestrzennym. Względem art. 2 pkt 1 w systemie Legalis występowało łącznie 39, a w systemie LEX 64 tezy orzecznicze. Natomiast względem art. 6 w systemie Legalis występowało 338 tezy orzecznicze, a w systemie LEX 421 tez orzeczniczych (łącznie zweryfikowano więc 862 tezy orzecznicze, oczywiście zakładając, że w obu systemach tezy się powtarzają). Tezy orzecznicze sklasyfikowano jako: 
- tezy stanowiące uzasadnienie (podstawę) dla wprowadzenia ograniczeń w zabudowie,

- tezy stanowiące uzasadnienie dla szerszej ochrony ładu przestrzennego,

- tezy neutralne.

Te ostatnie to tezy albo niedotyczące wprost wskazanego problemu, albo bardzo ogólnie sformułowane (w konsekwencji nie wynikają z nich żadne wnioski), albo wprost ograniczające się do powielania wyrażeń ustawowych. Ujęcie konkretnej tezy orzeczniczej w danej grupie nie jest równoznaczne z jej pozytywną/negatywną oceną z perspektywy formalnoprawnej (tym bardziej, że trzeba podkreślić zróżnicowane stany faktyczne stanowiące podstawę dla wydania poszczególnych orzeczeń). Poniżej przeprowadzono szerszą dyskusję na temat konkretnych kierunków orzeczniczych. Jest to bardzo istotne, niemniej w ramach samej klasyfikacji nie można jednoznacznie przyjąć, że opowiedzenie się przez sąd w określonym przypadku za możliwością zabudowy jest szkodliwe dla ładu przestrzennego i zasługuje na krytykę z perspektywy wartości systemu gospodarki przestrzennej. Systemy informacji prawnej Legalis i LEX zawierają często te same tezy orzecznicze. Z perspektywy artykułu nie stanowi to jednak istotnego zagadnienia. Chodzi bowiem nie tylko o charakterystykę orzecznictwa jako całości (tym problemom poświęcono inne analizy), ale określenie faktycznego wpływu orzeczeń na praktykę (i ich konkretnego odbioru przez użytkowników przestrzeni i podmioty polityki przestrzennej). Ten aspekt może zostać zweryfikowany właśnie przez całościową analizę najbardziej popularnych systemów informacji prawnej. Jednocześnie należy podkreślić, że przy klasyfikacji tez orzeczniczych często muszą decydować konkretne podejścia składów orzeczniczych do danego zagadnienia. Nie można opierać się tylko na tym, czy dany wyrok prowadzi do ograniczenia lub poszerzenia możliwości zabudowy. Trzeba ocenić, jak od strony argumentacji prawnej jest to uzasadniane.

Jak wskazano powyżej, w ustawie o planowaniu i zagospodarowaniu przestrzennym wyodrębniono dwa przepisy (art. 2 pkt 1 oraz art. 6) i do tych przepisów dostosowano kierunkowo dalszą analizę zagadnień. Z perspektywy formalnoprawnej (znajdującej przełożenie na perspektywę związaną z polityką publiczną) to właśnie takie ujęcie wydaje się kluczowym, podstawowym punktem odniesienia.

Orzecznictwo odnoszące się do definicji pojęcia ładu przestrzennego z zasady dotyczy procedury wydawania decyzji o warunkach zabudowy i związku z ładem przestrzennym zasad kontynuacji funkcji i bliskiego sąsiedztwa (tabela 1). W bardzo szerokim zakresie występują tam orzeczenia z perspektywy ochrony ładu przestrzennego (i określania relacji między ładem przestrzennym a możliwymi ograniczeniami zabudowy) neutralne. Oznacza to albo powtarzanie regulacji ustawowych, albo formułowanie tez oczywistych i utartych w orzecznictwie. Tak też wygląda układ 
najnowszych opublikowanych orzeczeń. Można więc przyjąć, że przeciętny czytelnik zapoznający się z kolejnymi - zamieszczonymi w obu systemach - tezami orzeczniczymi nie uzyska przeświadczenia o szerszej konieczności ochrony ładu przestrzennego (w wymiarze przekraczającym ogólne deklaracje). Warto podkreślić, że nawet przy przepisie próbującym określić, czym jest ład przestrzenny, liczba tez orzeczniczych przemawiających na rzecz pogłębionej ochrony ładu przestrzennego jest porównywalna z liczbą tez orzeczniczych akcentujących szeroko prawa właścicieli nieruchomości do zabudowy. Trzeba rzecz jasna mieć na uwadze, że sprawy podlegające ocenie sądów są zróżnicowane (i nie zawsze każda wymaga pogłębionych rozważań o konieczności ochrony ładu przestrzennego) oraz że w imię ładu przestrzennego prawa do zabudowy też nie mogą być skrajnie ograniczane. Z drugiej strony jednak dokonywane z perspektywy urbanistycznej i geograficznej diagnozy stanu zagospodarowania przestrzennego kraju zawierają konkluzje o powszechnym problemie niekontrolowanej zabudowy. Uwzględniając niniejsze tendencje można wskazać, że powyższe proporcje tez orzeczniczych potwierdzają jednak wyrażane w literaturze poglądy o braku dostatecznej wrażliwości sądów administracyjnych na problematykę ochrony ładu przestrzennego.

Tabela 1. Orzeczenia w systemach informacji prawnej dotyczące art. 2 pkt 1 ustawy o planowaniu i zagospodarowaniu przestrzennym

\begin{tabular}{|l|c|l|}
\hline \multicolumn{1}{|c|}{ System informacji prawnej } & \multicolumn{1}{|c|}{ Legalis } & \multicolumn{1}{|c|}{ LEX } \\
\hline $\begin{array}{l}\text { Liczba orzeczeń stanowiących } \\
\text { uzasadnienie dla wprowadzania } \\
\text { ograniczeń w zabudowie }\end{array}$ & \multicolumn{1}{|c|}{13} & 14 \\
\hline $\begin{array}{l}\text { Liczba orzeczeń stanowiących } \\
\text { uzasadnienie dla szerszej ochrony } \\
\text { tadu przestrzennego }\end{array}$ & \multicolumn{1}{|c|}{12} & \multicolumn{1}{|c|}{40} \\
\hline Liczba orzeczeń neutralnych & \multicolumn{1}{|c|}{10} \\
\hline $\begin{array}{l}\text { Dominujące problemy } \\
\text { w orzecznictwie }\end{array}$ & $\begin{array}{l}\text { Rozumienie zasady dobrego } \\
\text { sąsiedztwa, rozumienie kontynuacji } \\
\text { funkcji (zastosowanie kryteriów } \\
\text { urbanistycznych przy tej okazji), } \\
\text { czasem zakres ingerencji w prawo } \\
\text { własności. Dużo orzeczeń } \\
\text { neutralnych przytacza ogólne } \\
\text { sformułowania }\end{array}$ & $\begin{array}{l}\text { Większość neutralnych: albo } \\
\text { przepisujących ustawę, albo } \\
\text { powtarzających oczywiste oceny (że } \\
\text { przy wydawaniu decyzji o warunkach } \\
\text { zabudowy pośrednio występuje tad } \\
\text { przestrzenny) }\end{array}$ \\
\hline $\begin{array}{l}\text { Najnowsze pięć tez orzeczniczych } \\
\text { (koniec listopada 2020 r.) }\end{array}$ & $\begin{array}{l}\text { Dwa uzasadniające ograniczenia } \\
\text { w zabudowie, pozostate neutralne }\end{array}$ & $\begin{array}{l}\text { Neutralne - ogólne powiązanie } \\
\text { instytucji decyzji o warunkach } \\
\text { zabudowy z ladem przestrzennym }\end{array}$ \\
\hline
\end{tabular}

Źródło: opracowanie własne.

Mając to na uwadze, warto przytoczyć ujęte w obu systemach wybrane tezy orzecznicze. Występują tu tezy dotyczące samej definicji ładu przestrzennego 
i konieczności jej szerszego zastosowania. WSA w Krakowie (wyrok z dnia 8.09.2011, II SA/Kr 830/11, Legalis) wskazał, że normy dotyczące usytuowania budynków, stanowiące część powołanych wyżej norm techniczno-budowlanych, zaliczyć można również do wymagań urbanistyki w zakresie ochrony ładu przestrzennego. Odwołanie się przez ustawodawcę do wymagań urbanistyki i architektury stanowi również konieczność odniesienia się do zasad i ocen o pozaprawnym pochodzeniu. Zatem przepis nakazujący uwzględnianie wymagań ładu przestrzennego, w tym urbanistyki i architektury, rodzi również w tym zakresie obowiązek przestrzegania także norm technicznych i np. estetycznych. W pojęciu ładu przestrzennego mieszczą się też pojęcia „urbanistyka” i „,architektura”. Należy więc przyjąć, że głównym źródłem wymagań w tym zakresie są nie tylko przepisy prawa budowlanego, ale i szczegółowe wymagania urbanistyki i architektury wiążące się z fachowymi opracowaniami autorskimi oraz wiedzą zawodową. WSA w Warszawie (wyrok z dnia 5.03.2010 r., IV SA/Wa 1964/09, Legalis) podkreśla jednoznacznie, że przesłanka ochrony ładu przestrzennego nie może zostać uznana za ogólną (a więc pośrednio - wymagającą zignorowania przy wykładni). Za pozytywne przykłady należy uznać próby przenoszenia zasady ochrony ładu przestrzennego do innych regulacji zawartych w ustawie o planowaniu i zagospodarowaniu przestrzennym. Na przykład NSA (wyrok z dnia 26.10.2017 r., II OSK 2711/15, Legalis) zrobił to przy okazji charakterystyki kryteriów poszerzania obszaru analizowanego (przy wydawaniu decyzji o warunkach zabudowy), wskazując, że o wielkości obszaru wyznaczonego do analizy, jak i „rozciągnięcia” tego obszaru w określonym kierunku, mogą decydować m.in. takie względy, jak istnienie zabudowy (czasami bardzo licznej) jedynie w jednym kierunku od granicy działki, oddzielenie przyjętych do analizy działek drogą publiczną czy skrzyżowaniem dróg publicznych, różnorodność zabudowy, duże odległości między budynkami znajdującymi się na sąsiednich działkach. W tym kontekście właśnie na podstawie wymogu ochrony ładu przestrzennego można próbować powstrzymać bardzo wątpliwą praktykę poszerzania tych obszarów tylko i wyłącznie w celu umożliwienia konkretnej zabudowy. Podobne ujęcie zostało zawarte w wyroku WSA w Łodzi z dnia 26.04.2017 r. (II SA/Łd 749/16, LEX), gdzie wskazano, że w sytuacji zwartego terenu osiedla, na którym nie budzi wątpliwości jednorodna zabudowa jednorodzinna ewentualnie z uzupełnioną towarzyszącą zabudową usługową, pojawienie się zabudowy wielorodzinnej stanowić może zakłócenie zastanego ładu przestrzennego. Do takiego zakłócenia dojść może w sytuacji, gdy budownictwo wielorodzinne miałoby się pojawić się nie na obrzeżach czy w bezpośrednim sąsiedztwie osiedla domów jednorodzinnych, a w jego centrum.

W wyrokach, których konkluzje uzasadnień ukierunkowane są na ochronę ładu przestrzennego, można zauważyć rozważania na temat relacji między prawem 
własności a ładem przestrzennym. NSA (wyrok z dnia 19.01.2018 r., II OSK 832/16, LEX) stwierdził, że o prymacie ładu przestrzennego nad prawem własności nie można mówić w znaczeniu odpowiadającym automatyzmowi przyznawania wyższości interesowi publicznemu nad indywidualnym interesem właściciela, oba te interesy powinny bowiem podlegać w konkretnym przypadku próbie wyważenia. Niemniej, jeżeli uwzględnienie żądania podmiotu występującego o ustalenie warunków zabudowy nie da się pogodzić z wymogiem zachowania ładu przestrzennego na określonym obszarze, tej kategorii ogólnej powinno zostać nadane pierwszeństwo. WSA w Warszawie (wyrok z dnia 27.05.2009 r., IV SA/Wa 1704/08, LEX) zaznaczył, że prawodawca, gwarantując konstytucyjnie ochronę własności i określając ramy korzystania z prawa własności nieruchomości w ustawie o planowaniu i zagospodarowaniu przestrzennym, nie przyznał normatywnie, w sferze wykonywania prawa własności, prymatu prawu zabudowy nieruchomości nad prawem do korzystania z nieruchomości sąsiednich, w kontekście znoszenia uciążliwości związanych z zabudową przyległych terenów. Stąd teza o rozstrzyganiu ewentualnych wątpliwości na rzecz swobody inwestowania jest nieuprawniona. Podobne stanowisko zajął WSA w Gliwicach (wyrok z dnia 22.01.2007 r., II SA/Gl 784/06, LEX), którego zdaniem ani Konstytucja, ani żaden inny akt prawny nie zakładają prymatu zasady swobody działalności gospodarczej w stosunku do innych wartości chronionych prawem. Tak więc dopuszczalna jest możliwość ograniczenia działalności gospodarczej poprzez elementy planu zagospodarowania, wymienione w art. 15 ust. 2 pkt 9 ustawy o planowaniu i zagospodarowaniu przestrzennym, $\mathrm{w}$ celu ukształtowania przestrzeni tworzącej ład w rozumieniu art. 2 pkt 1.

W wyodrębnionym orzecznictwie można znaleźć jednak stanowiska odmienne (a przynajmniej nie w pełni zgodne z powyższymi). Na przykład WSA w Poznaniu (wyrok z dnia 4.11.2009 r., IV SA/Po 477/09, LEX) wskazał, że definicja ładu przestrzennego, wprowadzona w art. 2 pkt 1 ustawy o planowaniu i zagospodarowaniu przestrzennym, jest definicją z obszaru doktryny urbanistycznej i w konsekwencji nie zawiera jednoznacznych normatywnych treści. Takie ujęcie, bez wskazania konieczności odwołania się do doktryny urbanistycznej, zdecydowanie osłabiłoby rolę ochrony ładu przestrzennego w dokonywanej wykładni. W kontekście wyważania relacji ład przestrzenny - prawo własności, można wyodrębnić zarówno wyroki akcentujące zupełną równość obu wartości, jak też wyroki zdecydowanie bardziej uwrażliwione na wątek ochrony praw do zabudowy. Przykładem pierwszego może być wyrok WSA we Wrocławiu z dnia 31.05.2016 r. (II SA/Wr 122/16, LEX), w którym wskazano, że zgodnie z zasadą „złotego środka”, odzwierciedlającą najlepiej istotę konstytucyjnej ochrony prawa własności, postanowienia miejscowego planu zagospodarowania przestrzennego nie powinny być interpretowane w sposób nadmiernie 
ograniczający prawa właściciela ani w sposób nadmiernie rozszerzający istniejące ograniczenia praw właścicielskich, tak aby nie naruszało to istoty prawa własności. Natomiast przykładem drugiego - wyrok NSA z dnia 26.01.2007 r. (II OSK 239/06, LEX), w którym podkreślono, że nie można przyjąć, by przy braku miejscowego planu zagospodarowania przestrzennego dbałość o ład była realizowana przez bardzo restrykcyjne rozumienie przepisów prowadzące do odmowy ustalenia warunków zabudowy, wstrzymania wszelkich procesów inwestycyjnych, uniemożliwiając realizację zagwarantowanego konstytucyjnie prawa własności, w tym - stanowiącego element treści tego prawa - określonego w art. 6 ust. 2 pkt 1 ustawy o planowaniu i zagospodarowaniu przestrzennym prawa do zagospodarowania terenu.

Tabela 2. Orzeczenia w systemach informacji prawnej dotyczące art. 6 ustawy o planowaniu i zagospodarowaniu przestrzennym

\begin{tabular}{|c|c|c|}
\hline System informacji prawnej & Legalis & LEX \\
\hline $\begin{array}{l}\text { Liczba orzeczeń stanowiących } \\
\text { uzasadnienie dla wprowadzania } \\
\text { ograniczeń w zabudowie }\end{array}$ & 77 & 100 \\
\hline $\begin{array}{l}\text { Liczba orzeczeń stanowiących } \\
\text { uzasadnienie dla szerszej ochrony } \\
\text { tadu przestrzennego }\end{array}$ & 68 & 57 \\
\hline Liczba orzeczeń neutralnych & 193 & 267 \\
\hline $\begin{array}{l}\text { Dominujące problemy } \\
\text { w orzecznictwie }\end{array}$ & $\begin{array}{l}\text { Zakres ograniczeń w miejscowym } \\
\text { planie zagospodarowania } \\
\text { przestrzennego, określanie co ma } \\
\text { prymat: ład przestrzenny czy prawo } \\
\text { własności. Orzeczenia neutralne: } \\
\text { strony w postępowaniu, interes } \\
\text { prawny }\end{array}$ & $\begin{array}{l}\text { Zakres możliwej ingerencji } \\
\text { gmin w miejscowym planie } \\
\text { zagospodarowania przestrzennego, } \\
\text { zakres zastosowania zasady ładu } \\
\text { przestrzennego, kiedy ingerencja } \\
\text { nadmierna, jej uzasadnienie }\end{array}$ \\
\hline $\begin{array}{l}\text { Najnowsze pięć tez orzeczniczych } \\
\text { (koniec listopada } 2020 \text { r.) }\end{array}$ & $\begin{array}{l}\text { Jedna teza uzasadniająca } \\
\text { ograniczenia zabudowy, jedna } \\
\text { teza uzasadniająca poszerzanie } \\
\text { możliwości zabudowy, pozostałe } \\
\text { neutralne }\end{array}$ & $\begin{array}{l}\text { Jedna teza uzasadniająca } \\
\text { ograniczenia zabudowy, jedna } \\
\text { teza uzasadniająca poszerzanie } \\
\text { możliwości zabudowy, pozostałe } \\
\text { neutralne }\end{array}$ \\
\hline
\end{tabular}

Źródło: opracowanie własne.

Z zestawienia w tabeli 2 wynika, że w obu systemach dominowały tezy orzecznicze tak naprawdę neutralne z perspektywy określenia zakresu możliwej ingerencji planistycznej i jej relacji do prawa własności. Były tam zawarte przede wszystkim tezy dotyczące rozumienia interesu prawnego w konkretnych postępowaniach, tezy powielające stwierdzenia ustawowe (lub w inny sposób oczywiste) lub też tezy odnoszące się do zagadnień szczegółowych. Zauważalne jest to również przy analizie najnowszych tez orzeczniczych. Całościowa weryfikacja niniejszych tez orzeczniczych skłania jednocześnie do wniosku, że - poza tezami neutralnymi (z analizowanej 
perspektywy) - występuje przewaga tez stanowiących podstawę do argumentacji związanej z szerszym stopniem ingerencji gminy nad tezami stanowiącymi podstawę dla poszerzania możliwości zabudowy. $\mathrm{O}$ ile nie budziło wątpliwości, że ramy ingerencji planistycznej wyznaczane są przez ustawy (i ingerencja planistyczna musi być uzasadniona), o tyle kluczowym punktem odniesienia było postawienie konkretnych akcentów, a także określenie, co ma prymat w relacjach ład przestrzenny/ interes publiczny/ingerencja planistyczna gminy - prawa właścicieli nieruchomości/interesy indywidualne.

Przy klasyfikacji poszczególnych tez orzeczniczych warto pamiętać o tym, że czasami o zróżnicowanym ujęciu decydują szczegóły (lub nawet sam sposób przedstawienia określonej argumentacji). W badanym orzecznictwie zauważalne są jednak rozbieżności. W pierwszej kolejności można przytoczyć tezy dotyczące szerokiego zakresu samodzielności planistycznej gmin. WSA w Poznaniu (wyrok z dnia 31.01.2020, II SA/Po 890/19, Legalis) wskazał, że o nadużyciu władztwa planistycznego można twierdzić nie w sytuacji wyłącznie różnego przeznaczenia terenów, ale dopiero wówczas, gdy dochodzi do jaskrawego naruszania praw adresatów planu przy braku jakiegokolwiek uzasadnienia bądź w celu osiągnięcia nieproporcjonalnie mniej cennych wartości. WSA w Gdańsku (wyrok z dnia 11.04.2017 r., II SA/ Gd 72/17) wskazał, że koncepcja władztwa planistycznego oznacza, że w niektórych przypadkach ustalenia planu mogą ingerować $\mathrm{w}$ interesy prywatne podmiotów skarżących w sposób odbierany przez nie jako niekorzystny, natomiast nie musi z tym być powiązane przekroczenie granic władztwa planistycznego. Niniejszy pogląd z perspektywy użytkowników przestrzeni naświetlił NSA (wyrok z dnia 25.04.2018 r., II OSK 2382/17, Legalis), podkreślając, że podmioty dysponujące w granicach administracyjnych gmin prawem własności terenów, zabudowy o określonych walorach czy cechach (np. zabytkowych) muszą się liczyć z pewnymi przywilejami władz, mającymi swoje źródło w przepisach rangi ustawowej, dających możliwość wpływu na dysponowanie daną nieruchomością, w tym możliwością jej zabudowy. Jak zaznaczył WSA w Gdańsku (wyrok z dnia 22.03.2017 r., II SA/Gd 27/17, Legalis), jeżeli podmiot gospodarczy może inwestować na terenie gminy, to nie sposób mówić o pozbawieniu go prawa do swobodnego rozpoczęcia i prowadzenia działalności gospodarczej tylko z tej przyczyny, że procesy te powinny następować na warunkach określonych przez organ stanowiący gminy w treści planu. Nie można bowiem tej wolności rozumieć w sposób absolutny, pozbawiający organy gmin ich kompetencji wynikających z władztwa planistycznego.

Osobny problem to określanie priorytetów przy wyważaniu celów związanych z ochroną ładu przestrzennego a prawem własności. W tym kontekście należy powołać stanowisko NSA (z dnia 4.11.2011 r., II OSK 1855/11, Legalis), zgodnie z którym nie 
sposób podzielić poglądu, że konfrontacja pomiędzy własnością a ładem przestrzennym musi wypadać na korzyść własności, gdyż tylko taka interpretacja zachowuje własność jako prawo podstawowe. Ład przestrzenny ze swej istoty prawie w każdym przypadku wchodzi w kolizję z prawem własności. Oznaczałoby to, że w praktyce ład przestrzenny w zasadzie nie mógłby być realizowany. NSA w innej tezie (zawartej w wyroku z dnia 28.03.2014 r., II OSK 2618/12, Legalis) wskazuje, że nie można z prawa własności wywodzić prawa do zabudowy jako nieodzownego elementu tego prawa. Chociaż prawo do zabudowy stanowi najszerszą formę korzystania $\mathrm{z}$ nieruchomości gruntowej, to jednak nie daje ono właścicielowi pełni władzy nad rzeczą i nie ma charakteru prawa nieograniczonego. Tak samo (zdaniem WSA w Lublinie, wyrok z dnia 12.04.2012, II SA/Lu 84/12, Legalis) dokonywanie wykładni miejscowego planu zagospodarowania przestrzennego na korzyść uprawnień właścicielskich mogłoby znaleźć zastosowanie wyłącznie w przypadku pojęć niejasnych, których znaczenia prawnego nie można ustalić przy uwzględnieniu wykładni językowo-logicznej. Wolność zabudowy nie oznacza bowiem dowolności w zagospodarowaniu terenu, które to ustalenia należą do organu prawodawczego gminy poprzez uchwalenie planu miejscowego.

Niezależnie od tego w badanej grupie można znaleźć odmienne tezy orzecznicze. Najbardziej radykalne stanowisko wyrażono m.in. w wyroku WSA w Krakowie (z dnia 11.04.2011 r., II SA/Kr 79/11, Legalis) oraz wyroku WSA w Poznaniu (z dnia 2.07.2009 r., IV SA/Po 255/09, Legalis), gdzie przyjęto (z perspektywy samej wykładni prawnej rażąco błędną) tezę, zgodnie z którą organy nie mogą przyjąć automatycznie prymatu ładu przestrzennego nad prawem własności. W podobnym kierunku idą tezy NSA ( $\mathrm{z}$ dnia 26 listopada 2019 r., II OSK 76/18, LEX, z dnia 28.10.2016 r., II OSK 165/15, LEX), zgodnie z którymi brzmienie przepisów ustawy o planowaniu i zagospodarowaniu przestrzennym jednoznacznie wskazuje, że „interes publiczny” nie uzyskał prymatu w odniesieniu do interesu jednostki. Przyjęte w tej ustawie rozwiązania prawne oparte są zdaniem sądu na zasadzie równowagi interesu ogólnopaństwowego, interesu gminy i interesu jednostki. Ma to szczególne znaczenie w przypadku kolizji tych interesów, w tym interesu gminy $\mathrm{z}$ interesem obywateli wynikającym np. z prawa własności nieruchomości.

Występują również tezy szerzej wiążące prawo zabudowy z prawem własności. WSA w Bydgoszczy (wyrok z dnia 21/06.2011 r., II SA/Bd 461/11, Legalis) wskazał, że ustanowione w art. 6 ust. 2 ustawy o planowaniu i zagospodarowaniu przestrzennym prawo do zabudowy jest elementem prawa własności, a tym samym przejawem prawa do korzystania z rzeczy. Ograniczenia prawa do zabudowy mogą być wprowadzane na podstawie rozlicznych ustaw materialnych. Ewentualne regulacje planistyczne także mogą ograniczać to prawo, ale ograniczenia te nie mogą być interpretowane 
rozszerzająco. Tak samo można wyodrębnić tezy orzecznicze nakazujące wyjaśniać wątpliwości w wykładni planu miejscowego na rzecz właściciela nieruchomości (m.in. wyrok NSA z dnia 26.10.2017 r., II OSK 311/16, LEX).

Można przywołać tu również wyrok NSA z dnia 27.05.2011 r. (II OSK 499/11, Legalis), zgodnie z którym bez szczegółowego wykazania uzasadnionych przyczyn wprowadzenia odrębności na danym terenie można skutecznie zarzucić, iż dopuszczono się przekroczenia nadużywanego, jak się wydaje, określenia „władztwa planistycznego", doprowadzając w konsekwencji również do niezgodności z podstawowymi zasadami konstytucyjnymi (zasadą równości - wobec bezzasadnego różnicowania praw obywateli, zasadą ochrony własności, skoro bez ważnej, usprawiedliwionej przyczyny właściciel nieruchomości w danej gminie ma mniej praw od tego, którego nieruchomość leży w innej gminie, w której obowiązują ogólne przepisy w zakresie odległości obiektów budowlanych).

\section{$* * *$}

Z przeprowadzonych badań wynika, że sądy administracyjne (które, zwłaszcza w kontekście nauk o polityce publicznej, należy traktować jako władze publiczne posiadające realny wpływ na uwarunkowania przestrzenne) podchodzą w sposób bardzo zróżnicowany do problemu relacji interes publiczny/ład przestrzenny - prawo własności/wolność zagospodarowania. Po pierwsze mocnego podkreślenia wymaga fakt, że całościowo układ i zestawienie tez orzeczniczych względem analizowanych przepisów przy wskazanych systemach informacji prawnej nie dają jednoznacznej podstawy dla ochrony ładu przestrzennego. Jest to o tyle problematyczne, że ochrona ładu przestrzennego powinna być kluczowym celem systemu gospodarki przestrzennej. Osoba poszukująca argumentacji w tym zakresie znajdzie ją we wskazanych orzeczeniach. Jednak z perspektywy analizy wszystkich tez orzeczniczych nie będzie to argumentacja jasna, niebudząca wątpliwości. Niniejszy stan faktyczny może się przyczyniać (i przyczynia się) do negatywnych z perspektywy ładu przestrzennego praktyk.

Jednocześnie trzeba zauważyć, że o ile sądy administracyjne nie mogą orzekać w oderwaniu od podstaw prawnych, o tyle w możliwych ramach orzeczniczych występuje pewna szansa manewru. Sprowadza się ona do odpowiedzi na pytania o realne znaczenie ładu przestrzennego w ustawie o planowaniu i zagospodarowaniu przestrzennym oraz określania relacji między ochroną ładu przestrzennego a prawem własności właścicieli nieruchomości. Z tej perspektywy bardzo krytycznie należy ocenić stanowiska orzecznicze, które nie przyznają prymatu interesu publicznego nad indywidualnymi interesami podmiotów prywatnych w systemie gospodarki przestrzennej. Świadczą one o niezrozumieniu całościowego kontekstu przestrzennego spraw stanowiących przedmiot orzeczeń ani możliwych konsekwencji tych 
orzeczeń. W związku z tym należy w pełni opowiedzieć się za wykładnią, w ramach której ład przestrzenny powinien być w miarę możliwości konkretyzowany również w przepisach dotyczących planowania i zagospodarowania przestrzennego, także poprzez odwołanie do sformułowań nieprawniczych. Z drugiej strony tego typu oceny (dokonywane w ramach wykładni) nie mogą być zbyt daleko idące (nie można np. akceptować odmowy ustalenia warunków zabudowy tylko i wyłącznie na podstawie samej zasady ochrony ładu przestrzennego). Dyskutując o wpływie sądów na system gospodarki przestrzennej, trzeba również podkreślić, że często powinien on być rozpatrywany z perspektywy konsekwencji działań lub zaniechań organów gmin, podstawowych podmiotów prowadzących politykę przestrzenną.

\section{Bibliografia}

Cotella, G. (2014). Spatial planning in Poland between European influence and dominant market forces. W: Spatial planning systems and practices in Europe. A comparative perspective on continuity and changes: 255-277), M. Reimer, P. Getimis, H. Blotevogel (eds.). New York, NY: Routledge. DOI:10.4324/9781315852577.

Gdesz, M. (2020). Ład przestrzenny z perspektywy orzecznictwa sądów administracyjnych. W: Ochrona ładu przestrzennego z perspektywy prawno-urbanistycznej: 46-65, M. Nowak (red.). Warszawa: Wolters Kluwer.

Izdebski, H. (2013). Ideologia i zagospodarowanie przestrzeni. Warszawa: Wolters Kluwer Business.

Izdebski, W., Śleszyński, P., Malinowski, Z., Kursa, M. (2018). Analiza morfometryczna planów miejscowych w Polsce. Infrastruktura i ekologia terenów wiejskich, N II/1/2018: 331-340.

Korbel, W. (2017). Słabości miejscowych planów zagospodarowania przestrzennego w praktyce ich stosowania. W: Teoretyczne i praktyczne aspekty prawa gospodarki przestrzennej: 103-116, W. Ratajczak, M. Szewczyk, J. Weltrowska (red.). Poznań: Wydawnictwo Naukowe Bogucki.

Kowalewski, A. (2019). Interes publiczny i przestrzeń - kilka uwag. W: Zarzadzanie rozwojem współczesnych miast: 265-267, J. Danielewicz, D. Sikora-Fernandez (red.). Łódź: Wydawnictwo Uniwersytetu Łódzkiego.

Kowalewski, A., Mordasewicz, J., Osiatyński, J., Regulski, J., Stępień, J., Śleszyński, P. (2014). Ekonomiczne straty i społeczne koszty niekontrolowanej urbanizacji w Polsce - wybrane fragmenty raportu, Samorzad Terytorialny, 4: 5-21. http://yadda.icm.edu.pl/yadda/element/bwmeta1.element.ekon-element-000171274925 (dostęp: 14.03.2021).

Kowalewski, A., Nowak, M. (2018). Chaos przestrzenny i prawo. Uwarunkowania, procesy, skutki, rekomendacje. W: Studia nad chaosem przestrzennym: 128-136), A. Kowalewski, T. Markowski, P. Śleszyński (red.). Warszawa: Studia KPZK PAN, t. CLXXXII, t. I. http:// journals.pan.pl/dlibra/publication/125356/edition/109381/content (dostęp: 14.03.2021).

Krawczyk, M. (2018). W poszukiwaniu ładu przestrzennego. W: Prawne problemy rozpraszania i koncentrowania zabudowy (33-44), T. Bąkowski (red.). Gdańsk: Wydawnictwo Uniwersytetu Gdańskiego. 
Kudłacz, T. (2015). Problems of Integration of Spatial and Socio-Economic Planning on Local Level

In Poland. W: Integrated Development and Spatial Management of Urban Areas. Polish Experience. Studia Regionalia, 43/44: 42-52. https://journals.pan.pl/dlibra/publication/112996/ edition/98256/content (dostęp: 14.03.2021).

Majda, T. (2020). Miejscowy plan zagospodarowania przestrzennego - uwarunkowania i przykłady dobrych praktyk. W: Ochrona ładu przestrzennego z perspektywy prawno-urbanistycznej: 129-158, M. Nowak (red.). Warszawa: Wolters Kluwer.

Markowski, T. (2010). Planowanie przestrzenne i instrumenty jego realizacji w świetle teorii ułomnych rynków. W: Zarządzanie rozwojem przestrzennym miast: 12-31, P. Lorens, J. Martyniuk-Pęczek (red.). Gdańsk: Wydawnictwo Urbanista.

Markowski, T. (2011). Funkcjonowanie gospodarki przestrzennej - założenia budowy modelu zintegrowanego planowania i zarządzania rozwojem. W: System planowania przestrzennego i jego rola $w$ strategicznym zarzadzaniu rozwojem kraju: 25-44, T. Markowski, P. Żuber (red.). Warszawa: Studia KPZK PAN, t. CXXXIV.

Markowski, T. (2014). Zintegrowane planowanie rozwoju. W: Przyszłość Wolności, wymiar krajowy - regionalny - międzynarodowy: 335-367, A. Kukliński, J. Woźniak (red.). Kraków: Biblioteka Małopolskiego Obserwatorium Polityki Rozwoju.

Nowak, M. (2012). Decyzje o warunkach zabudowy i zagospodarowania terenu $w$ gospodarowaniu i zarzadzaniu przestrzenia. Warszawa: $\mathrm{CeDeWu}$.

Nowak, M. (2017a). Niesprawność władz publicznych a system gospodarki przestrzennej. Warszawa: Studia KPZK PAN, t. CLXXV. https://journals.pan.pl/dlibra/publication/118561/ edition/103144/content (dostęp: 14.03.2021).

Nowak, M. (2017b). The Stakeholders and Municipal Authorities in the Spatial Competition. Biuletyn KPZK PAN, 265: 22-35. https://journals.pan.pl/dlibra/publication/115942/ edition/100772/content (dostęp: 14.03.2021).

Nowak, M. (2020). Planowanie i zagospodarowanie przestrzenne. Komentarz do ustawy i przepisów powiązanych. Warszawa: $\mathrm{CH}$ Beck.

Nowak, M., Kreja, P. (2012). Decyzje o warunkach zabudowy i zagospodarowania terenu jako instrument polityki przestrzennej w polskich metropoliach, Świat Nieruchomości, 2(80): 4-9. http://yadda.icm.edu.pl/yadda/element/bwmeta1.element.ekon-element-000171252453 (dostęp: 14.03.2021).

Nowak, M., Lorens, P. (2020). Ochrona i kształtowanie ładu przestrzennego w miejscowych planach zagospodarowania przestrzennego. Propozycje kierunku wykładni. W: Ochrona ładu przestrzennego z perspektywy prawno-urbanistycznej: 104-128, M. Nowak (red.). Warszawa: Wolters Kluwer.

Nowak, M., Śleszyński, P., Ostrowska, A. (2020). Orzeczenia sądów administracyjnych w systemie gospodarki przestrzennej - perspektywa funkcjonalna i realizacyjna. Studium przypadku województwa mazowieckiego. Samorzą Terytorialny, 7-8: 109-128. http:// bazekon.icm.edu.pl/bazekon/element/bwmeta1.element.ekon-element-000171601587 (dostęp: 14.03.2021). 
Ostrowska, A. (2017). Rozważania nad istnieniem i istotą wolności zabudowy - głos w dyskusji. Annales Universitatis Mariae Curie-Skłodowska, Sectio G, LXIV, I: 153-170. http://yadda.icm. edu.pl/yadda/element/bwmeta1.element.ekon-element-000171494032 (dostęp: 14.03.2021).

Parysek, J.J. (2010). Urban policy in the context of contemporary urbanisation processes and development issues of Polish cities. Journal of Urban and Regional Analysis, 2(2): 33-44. http://www.jurareview.ro/resources/pdf/volume_6_urban_policy_in_the_context_of_ contemporary_urbanisation_[wuprocesses_and_development_issues_of_polish_cities_ abstract.pdf (dostęp: 14.03.2021).

Reimer, M., Getimis, P., Blotevogel, H. (2014). Spatial planning systems and practices in Europe: a comparative perspective. W: Spatial planning systems and practices in Europe. A comparative perspective on continuity and changes: 1-20, M. Reimer, P. Getimis, H. Blotevogel (eds.). New York, NY: Routledge. DOI: 10.4324/9781315852577.

Rzucidło, I. (2020). Uzasadnienie orzeczenia sądowego. Ujęcie teoretyczne a poglady orzecznictwa. Warszawa: Wolters Kluwer.

Śleszyński, P. (2018a). Potencjalne koszty odszkodowawcze związane z niewłaściwym planowaniem przestrzennym w gminach. W: Koszty chaosu przestrzennego: 404-424, A. Kowalewski, T. Markowski, P. Śleszyński (red.). Warszawa: Studia KPZK PAN, 182. https:// journals.pan.pl/dlibra/publication/123416/edition/107645/content (dostęp: 14.03.2021).

Śleszyński, P. (2018b). Społeczno-ekonomiczne skutki chaosu przestrzennego dla osadnictwa i struktury funkcjonalnej terenów. W: Koszty chaosu przestrzennego: 29-80, A. Kowalewski, T. Markowski, P. Śleszyński (red.). Warszawa: Studia KPZK PAN, 182. https://journals. pan.pl/dlibra/publication/123405/edition/107634/content (dostęp 14.03.2021).

Śleszyński, P., Kowalewski, A., Markowski, T., Legutko-Kobus, P., Nowak, M. (2020). The Contemporary Economic Costs of Spatial Chaos: Evidence from Poland. Land, 9(7): 2-28. DOI: $10.3390 /$ land 9070214 .

Woźniak, M. (2018). Interes publiczny i interes indywidualny w planowaniu i zagospodarowaniu przestrzennym. Opole: Uniwersytet Opolski.

Zachariasz, I. (2015). Nowelizacja prawa planowania i zagospodarowania przestrzennego. W: Sprawne państwo. Propozycje zmian w funkcjonowaniu jednostek samorzadu terytorialnego: 118-134, P. Kopyciński (red.). Kraków: Małopolska Szkoła Administracji Publicznej.

Zybała, A. (2019). Polityka przestrzenna i jej rezultaty w warunkach rosnącej złożoności jej problemów. Studia z Polityki Publicznej, 6(2): 103-122. DOI: 10.33119/KSzPP/2019.2.5.

Unless stated otherwise, all the materials are available under the Creative Commons Attribution 4.0 International license. Some rights reserved to SGH Warsaw School of Economics.

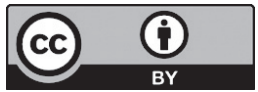

